\title{
Correction to: Radiological evaluation of malignant pleural mesothelioma - defining distant metastatic disease
}

Dearbhaile Catherine Collins ${ }^{1}$, Raghav Sundar ${ }^{1}$, Anastasia Constantinidou', David Dolling ${ }^{1}$, Timothy Anthony Yap ${ }^{1}$, Sanjay Popat ${ }^{2}$, Mary E. O'Brien ${ }^{3}$, Udai Banerji' $^{1}$, Johann Sebastian de Bono ${ }^{1}$, Juanita Suzanne Lopez ${ }^{1}$,

Nina Tunariu' ${ }^{1}$ and Anna Minchom ${ }^{1 *}$

Correction to: BMC Cancer 20, 1210 (2020)

https://doi.org/10.1186/s12885-020-07662-y

Following publication of the original article [1], the authors identified an error in the author name of Anastasia Constantinidou.

The incorrect author name is: Anastasia Constantidinou

The correct author name is: Anastasia Constantinidou

The author group has been updated above and the original article [1] has been corrected.

\begin{abstract}
Author details
1Drug Development Unit, Royal Marsden Hospital/ Institute of Cancer Research, Down Rd., Sutton SM2 5PT, UK. ${ }^{2}$ Lung Unit, Royal Marsden Hospital, Fulham Rd., London SW3 6JJ, UK. ${ }^{3}$ Lung Unit, Royal Marsden Hospital, Sutton SM2 5PT, UK.
\end{abstract}

Published online: 08 March 2021

\section{Reference}

1. Collins DC, Sundar R, Constantinidou A, et al. Radiological evaluation of malignant pleural mesothelioma - defining distant metastatic disease. BMC Cancer. 2020;20:1210. https://doi.org/10.1186/s12885-020-07662-y.

The original article can be found online at https://doi.org/10.1186/s12885020-07662-y

* Correspondence: anna.minchom@icr.ac.uk

${ }^{1}$ Drug Development Unit, Royal Marsden Hospital/ Institute of Cancer Research, Down Rd., Sutton SM2 5PT, UK

Full list of author information is available at the end of the article

(C) The Author(s). 2021 Open Access This article is licensed under a Creative Commons Attribution 4.0 International License, which permits use, sharing, adaptation, distribution and reproduction in any medium or format, as long as you give appropriate credit to the original author(s) and the source, provide a link to the Creative Commons licence, and indicate if changes were made. The images or other third party material in this article are included in the article's Creative Commons licence, unless indicated otherwise in a credit line to the material. If material is not included in the article's Creative Commons licence and your intended use is not permitted by statutory regulation or exceeds the permitted use, you will need to obtain permission directly from the copyright holder. To view a copy of this licence, visit http://creativecommons.org/licenses/by/4.0/. The Creative Commons Public Domain Dedication waiver (http://creativecommons.org/publicdomain/zero/1.0/) applies to the data made available in this article, unless otherwise stated in a credit line to the data. 